\title{
Root Morphology and Tooth Length of Maxillary First Premolar in Nepalese Population
}

\section{Kafle Dashrath ${ }^{1 *}$, Acharya Nisha ${ }^{2}$ and Sthapit Subodh ${ }^{3}$}

${ }^{1}$ Department of Orthodontics, Kathmandu University School of Medical Sciences, Dhulikhel Hospital, Dhulikhel, Nepal

${ }^{2}$ Universal College of Dental Sciences, Bhairahawa, Nepal

${ }^{3}$ University of East, Manila, Philippines

\begin{abstract}
Introduction: Maxillary first premolar teeth are commonly extracted teeth for orthodontic purpose and commonly root treated tooth because of dental caries. There are different variations on root form, number as well length of the root and tooth.

Objective: To find out the root morphology and average tooth and root length of maxillary first premolars in Nepalese population samples.

Materials and methods: Total 100 maxillary first premolar teeth were collected for the study and carefully stored in chambers separated for male and female. Root form was identified and recorded. Similarly tooth length and root length was measured by digital caliper (MC, China) and compared by independent t-test.

Result: $58 \%$ of the samples had single rooted roots. Whereas double root, fused root and triple root form were $20 \%$, $21 \%$ and $1 \%$ respectively. There was not any significant difference on male and female toot and root length.

Conclusion: Majority of Nepalese premolars have a tendency to be single rooted. Overall tooth length is shorter than the established tooth length.
\end{abstract}

Keywords: Maxillary first premolar; Root form; Root length; Tooth length

\section{Introduction}

Orthodontic treatment is usually associated with dental extraction and maxillary first premolar teeth are most commonly extracted teeth for this purpose [1-5]. Maxillary premolars are also commonly affected by dental caries which necessitates the need of root canal treatment. These teeth are found to have numerous variations in root form as well as root canal system which is of importance for general dentists as well as endodontists. First premolars being located in between anterior and posterior segment, they resemble with canine and molars in form as well as function [6]. On labial view, maxillary first premolars resemble more closely with maxillary canines where as they resemble the function of molar mostly i.e., grinding and chewing food. In absence of molars, premolars do the function of chewing food particles. However they are also used for tearing the food which is primarily the function of canines. Maxillary first premolars are usually thought to have two roots. However there are numerous racial differences on the root form, number of root and root canal system [7-10]. Extraction of maxillary first premolar might be difficult, especially when it has two separate roots. In orthodontic practice, therapeutic extraction of these teeth should be performed cautiously. When there is fracture of roots, extreme precaution should be taken to preserve the buccal cortical plate. If prior information about the number and curvature of root is known then necessary precautions can be taken while performing any clinical procedures. The established normal value of maxillary first premolar crown and root length are $8.5 \mathrm{~mm}$ and $14 \mathrm{~mm}$ respectively [11]. But these values might not be applicable in all the populations [12]. There are very scanty publications regarding the root forms of the south Asian populations and there are not any researches in Nepalese samples so far. So this study was designed to find out the facts about root form, tooth and root length in Nepalese population samples.

\section{Materials and Methods}

Total 100 maxillary first premolar teeth that are extracted for routine orthodontic procedure in Dhulikhel Hospital, Kathmandu University School of Medical Sciences are collected for the study. The tooth immediately after extraction is rinsed with water to clean the blood debris then dipped into 5.2\% Sodium Hypochlorite solution for two minutes and stored in $10 \%$ formalin until measurements are done. While collecting the teeth, male and female teeth are collected in a separate collection bottles with clearly written labels. Verbal consent is obtained from patient to keep their extracted teeth in hospital. In case the patients who wanted to take their extracted teeth with them, the teeth were given. Teeth with fractured and incompletely formed roots, with open apex and gross malformation are excluded from the study. The root forms were identified as single root, double root, triple root and fused root; described originally by Turner [13] later by Loh [9]. The root and tooth length are measured from mid buccal cemento-enamel junction and tip of buccal cusp to the root apex respectively with the help of a digital caliper (MC 01010157, $150 \mathrm{~mm}$, China). In case of double and triple rooted teeth, the measurement is taken up to the apex of the longest root. Descriptive analysis was done for the root from, tooth and root length. Root length and tooth length were compared between male and female samples by independent $t$-test. The $p$-value was kept 0.05 for the level of significance.

\section{Results}

The frequency distribution of the root from, tooth and root length

*Corresponding author: Dr. Dashrath Kafle, Assistant Professor, Department of Orthodontics, School of Dentistry, Kathmandu University Hospital, Dhulikhel Hospital, Dhulikel, Nepal; Tel: 009779849599583; E-mail: dashrath07@yahoo.com

Received June 24, 2015; Accepted July 27, 2015; Published August 07, 2015

Citation: Dashrath K, Nisha A, Subodh S (2015) Root Morphology and Tooth Length of Maxillary First Premolar in Nepalese Population. Dentistry 5: 324 doi:10.4172/2161-1122.1000324

Copyright: (c 2015 Dashrath K, et al. This is an open-access article distributed under the terms of the Creative Commons Attribution License, which permits unrestricted use, distribution, and reproduction in any medium, provided the original author and source are credited. 
is shown in Table 1. Out of 100 specimens, majority of the teeth had single root form $(58 \%, n=58)$ whereas double root $(n=20)$, fused $(n=$ 21 ) and triple root $(n=1)$ forms were $20 \%, 21 \%$ and $1 \%$ respectively.

The tooth length, root length as well as comparison of these measurements between two genders are shown in Table 2 . The average tooth length was $21 \mathrm{~mm}$ with minimum and maximum tooth length $17.52 \mathrm{~mm}$ and $24.69 \mathrm{~mm}$ respectively. The mean tooth length in male and female were $21.09 \pm 2.09 \mathrm{~mm}$ and $20.99 \pm 1.65 \mathrm{~mm}$ and mean root length were $13.08 \pm 2.00 \mathrm{~mm}$ and $12.63 \pm 1.50 \mathrm{~mm}$ respectively. The independent t-test did not show any significant difference on tooth and root length between male and female samples.

\section{Discussion}

The study was designed to obtain some idea about the root form, tooth length as well as root length of maxillary first premolar in Nepalese samples. So far there are no publications on root form and tooth length in Nepalese population. We have carefully stored the maxillary first premolar teeth immediately after extraction so that there is no confusion regarding the identifying characteristics of the tooth and to avoid possible biases.

In our study, $58 \%$ of the samples are found to have single root. There are varying reports from similar Asian studies. Walker and Loh in separate studies done in south-Chinese populations have found that $60 \%$ and $50 \%$ of their sample had single root $[9,10]$. Similarly a CBCT (Cone-Beam Computed Tomography) study done by Tian et al. in Chinese population has found that $66 \%$ of the maxillary first premolars had single root [14-16]. So Chinese population has more tendency towards having single root maxillary first premolar. However in contrast to our study and the Chinese studies, the studies done in Saudi and Jordanian population has shown the predominance of double rooted maxillary first premolars $[17,18]$.

Other non-Asian studies have however shown the predominance of double rooted maxillary first premolars $[6,7,12,15,19]$. Some authors have clearly divided root forms into single, double, fused and triple roots as shown in Table $3[6,9,18]$. The difference on prevalence of root form on different studies might be because of the different criteria followed. If we assume fused root are the variant of double root then our findings will also be different. Triple rooted maxillary first premolars are very rare entity. It is reported to be between $0.8-6 \%[6,7,9,12,18]$. In our study, only one sample had three roots.

Regarding the length of the tooth, our study has found that there is

\begin{tabular}{|c|c|c|c|c|c|}
\hline Sex & Single root & Double root & Fused root & Triple root & Total \\
\hline Male & $16(61.5 \%)$ & $4(15.4 \%)$ & $6(23.1 \%)$ & - & 26 \\
\hline Female & $42(56.8 \%)$ & $16(21.6 \%)$ & $15(20.3 \%)$ & $1(1.4 \%)$ & 74 \\
\hline Overall & $58(58 \%)$ & $20(20 \%)$ & $21(21 \%)$ & $1(1 \%)$ & 100 \\
\hline
\end{tabular}

Table 1: Root form distribution.

\begin{tabular}{|c|c|c|c|c|c|c|}
\hline $\begin{array}{c}\text { Tooth/Root } \\
\text { length }\end{array}$ & Sex & N & Mean & $\begin{array}{c}\text { Standard } \\
\text { Deviation }\end{array}$ & p-value & Significance \\
\hline Tooth length & & 64 & 21.00 & 1.77 & & \\
\hline Root length & & & 12.76 & 1.65 & & \\
\hline \multirow{2}{*}{ Tooth Length } & Male & 20 & 21.02 & 2.09 & 0.948 & NS \\
\cline { 2 - 7 } & Female & 46 & 20.99 & 1.65 & & \\
\hline Root Length & Male & 20 & 13.08 & 2.00 & 0.341 & NS \\
\hline & Female & 46 & 12.63 & 1.50 & & \\
\hline
\end{tabular}

NS: Not Significant

Table 2: Tooth length and root length measurement.

\begin{tabular}{|c|c|c|c|c|c|c|c|}
\hline Author & Year & Population & $\begin{array}{c}\text { Sample } \\
\text { size }\end{array}$ & $\begin{array}{l}\text { One } \\
\text { root }\end{array}$ & $\begin{array}{c}\text { Double } \\
\text { root }\end{array}$ & $\begin{array}{c}\text { Triple } \\
\text { root }\end{array}$ & $\begin{array}{c}\text { Fused } \\
\text { root }\end{array}$ \\
\hline Woelfel J [6] & 1990 & & 200 & 38 & 61 & 1 & \\
\hline $\begin{array}{c}\text { Chapparo AJ, } \\
\text { Segura JJ, } \\
\text { Guerrero E, } \\
\text { Jimenez-Rubio A, } \\
\text { Murillo C et al. [7] }\end{array}$ & 1999 & Spanish & 150 & 40 & 56.7 & 3.3 & \\
\hline Loh HS [9] & 1996 & Singaporean & 957 & 49.4 & 50.6 & - & 32.1 \\
\hline Walker RT [10] & 1987 & Chinese & 100 & 60 & 40 & - & - \\
\hline $\begin{array}{c}\text { Pecora JD, } \\
\text { Saquy PC, Sousa } \\
\text { Neto MD, Woelfel } \\
\text { JB [12] }\end{array}$ & 1992 & Brazilian & 240 & 55.8 & 41.7 & 2.5 & \\
\hline Ingle JI [14] & 1965 & & & 43 & 55 & - & 33 \\
\hline $\begin{array}{l}\text { Vertucci FJ, } \\
\text { Gegauff A [15] }\end{array}$ & 1979 & Caucassian & 400 & 26.2 & 70 & & 13.5 \\
\hline $\begin{array}{c}\text { Tian YY, Guo B, } \\
\text { Zhang R, Yu X, } \\
\text { Wang H, Hu T, et } \\
\text { al. }[16]\end{array}$ & 2012 & $\begin{array}{c}\text { Chinese } \\
\text { south }\end{array}$ & 300 & 66 & 33 & 1 & \\
\hline $\begin{array}{c}\text { Awawdeh L } \\
\text { Abdullah H, Al- } \\
\text { Qudah A. [17] }\end{array}$ & 2008 & Jordanian & 600 & 30.8 & 68.4 & .8 & \\
\hline Ateih MA [18] & 2008 & Saudi & 246 & 17.9 & 80.9 & 1.2 & \\
\hline $\begin{array}{c}\text { Rwenyonyi C, } \\
\text { Kutesa A, Muwazi } \\
\text { L, Buwembo W } \\
{[19]}\end{array}$ & 2011 & Uganda & 202 & 26.7 & 60.9 & & 12.37 \\
\hline Present Study & 2015 & Nepalese & 100 & 58 & 17.1 & 22.4 & 1.3 \\
\hline
\end{tabular}

Table 3: Root forms in different populations.

no significant difference on root and tooth length between males and female samples. The mean tooth length was $21 \mathrm{~mm}$ and root length was $12.76 \mathrm{~mm}$. This length is shorter than the established tooth and root length mentioned by Ash [11]. However the study done by Pecora on Brazilian population has found the result similar to our study. In their study, the mean length of the tooth was found to be $21.0 \mathrm{~mm}$ [12]. In our study the mean length is $21 \mathrm{~mm}$ with minimum $17.52 \mathrm{~mm}$ and maximum length $24.56 \mathrm{~mm}$.

\section{Conclusion}

Based on the findings of the study we conclude that the maxillary first premolars in Nepalese population have a tendency to be single rooted and tooth length is shorter than the previously established data.

\section{References}

1. Angelillo IF, Nobile CG, Pavia M (1996) Survey of reasons for extraction of permanent teeth in Italy. Community Dent Oral Epidemiol 24: 336-340.

2. Baqain ZH, Khraisat A, Sawair F, Ghanam S, Shaini FJ, et al. (2007) Denta extraction for patients presenting at oral surgery student clinic. Compend Contin Educ Dent 28: 146-150.

3. McCaul LK, Jenkins WM, Kay EJ (2001) The reasons for the extraction of various tooth types in Scotland: a 15-year follow up. J Dent 29: 401-407.

4. Reich E, Hiller KA (1993) Reasons for tooth extraction in the western states of Germany. Community Dent Oral Epidemiol 21: 379-383.

5. Sayegh A, Hilow H, Bedi R (2004) Pattern of tooth loss in recipients of free dental treatment at the University Hospital of Amman, Jordan. J Oral Rehabil 31: 124-130.

6. Woelfel J (2012) Dental anatomy (8thedn), Wolters Kluwer, Philadelphia.

7. Chaparro AJ, Segura JJ, Guerrero E, Jimenez-Rubio A, Murillo C, et al. (1999) Number of roots and canals in maxillary first premolars: study of an Andalusian population. Endod Dent Traumatol 15: 65-67. 
Citation: Dashrath K, Nisha A, Subodh S (2015) Root Morphology and Tooth Length of Maxillary First Premolar in Nepalese Population. Dentistry 5: 324. doi:10.4172/2161-1122.1000324

8. Jayasimha Raj U, Mylswamy S (2010) Root canal morphology of maxillary second premolars in an Indian population. J Conserv Dent 13: 148-151.

9. Loh HS (1998) Root morphology of the maxillary first premolar in Singaporeans. Aust Dent J 43: 399-402.

10. Walker RT (1987) Root form and canal anatomy of maxillary first premolars in a southern Chinese population. Endod Dent Traumatol 3: 130-134.

11. Ash MM (1993) Wheeler's Dental anatomy, physiology and occlusion. (7thedn), WB Saunders Company, Philadelphia, London, Toronto.

12. Pecora JD, Saquy PC, Sousa Neto MD, Woelfel JB (1992) Root form and canal anatomy of maxillary first premolars. Braz Dent J 2: 87-94.

13. Turner CG (1967) The dentition of the Arctic peoples. Doctoral dissertation for University of Wisconsin, Madison.

14. Ingle JI (1965) Endodontics. (1stedn), Lea and Febiger, Philadelphia.
15. Vertucci FJ, Gegauff A (1979) Root canal morphology of the maxillary first premolar. J Am Dent Assoc 99: 194-198.

16. Tian YY, Guo B, Zhang R, Yu X, Wang H, et al. (2012) Root and canal morphology of maxillary first premolars in a Chinese subpopulation evaluated using cone-beam computed tomography. Int Endod J 45: 996-1003.

17. Awawdeh L, Abdullah H, Al-Qudah A (2008) Root form and canal morphology of Jordanian maxillary first premolars. J Endod 34: 956-961.

18. Atieh MA (2008) Root and canal morphology of maxillary first premolars in a Saudi population. J Contemp Dent Pract 9: 46-53.

19. Rwenyonyi C, Kutesa A, Muwazi L, Buwembo W (2011) Root and canal morphology of maxillary first premolar teeth in a ugandan population. Open Journal of Stomatology 1: 7-11. 